\title{
A New Record of Melita bingoensis (Crustacea: Amphipoda: Melitidae) from Korea
}

\author{
Myung-Hwa Shin, Won Kim* \\ School of Biological Sciences, Seoul National University, Seoul 151-747, Korea
}

\begin{abstract}
A melitid species, Melita bingoensis Yamato, 1987 collected from the Yellow Sea, is reported for the first time in Korea. This species has a slit-like pocket in coxa 6 of female, which is not found in other Korean melitid amphipods. In this paper, we compared this species with three other previously known Korean species in the same genus.
\end{abstract}

Keywords: Melita bingoensis, Melitidae, Amphipoda, Korea

\section{INTRODUCTION}

The genus Melita Leach, 1814, from the family Melitidae, has a variramous uropod 3. Inner ramus of the appendage is shorter than outer ramous and setation pattern of rami are dissimilar to each other. This characteristic of the genus Melita indicates that they are one of the primitive groups (Barnard and Barnard, 1983).

Before this study, three species from the genus Melita were known in Korea: Melita koreana Stephensen, 1944, M. rylovae Bulycheva, 1955, and M. setiflagella Yamato, 1988 (Kim et al., 1992). Among them, M. rylovae is known to be associated with cultured abalones in Korea (Shin et al., 2005). Herein, Melita bingoensis Yamato, 1987 is reported for the first time as a member of the Korean amphipod fauna.

Our specimens were collected from the Yellow Sea, Korea, between 2008 and 2009. The specimens were preserved in 95\% ethanol. Dissection and mounting was conducted according to the methodology of Barnard and Karaman (1991). All specimens examined here were deposited in the Marine Arthropod Depository Bank of Korea (MADBK), Seoul National University.

\section{SYSTEMATIC ACCOUNTS}

Order Amphipoda Latreille, 1816

Family Melitidae Bousfield, 1973

Genus Melita Leach, 1814

$1 *$ Melita bingoensis Yamato, 1987 (Figs. 1, 2)

Melita bingoensis Yamato, 1987: 293, figs. 16-20.

Materials examined. Korea: $1 \sigma^{\top}, 1$ 우, Incheon, Ongjin-gun, Yeongheung-myeon, Seonjae-do, 9 May 2008; 9 ఠð immature 8, Gyeonggi-do, Hwaseong-si, Seosin-myeon, Jebu-do, 2 Oct 2008; 8 『 ๙ si, Seosin-myeon, Jebu-do, 28 Nov 2008; $5 \sigma^{\nearrow} \sigma^{\nearrow}$, Incheon, Ongjin-gun, Yeongheung-myeon, Seonjae-do, 5 Aug 2009.

Description. Male: Body (Fig. 1) $9.4 \mathrm{~mm}$ long (from the tip of rostrum to posterior end of urosomite 3), compressed. Eye black. Dorsal part of pleosomites 1-3, urosomite 1 and 3 smooth. Epimeron 1 subrounded ventrodistally; epimeron 2 having small ventrodistal tooth; epimeron 3 slightly extended posteriorly and forming distinct tooth (Fig. 2A). Urosomite 2 (Fig. 2B) with 3 spines on both sides in dorsal view.

Basis of gnathopod 1 (Fig. 2C) bearing rows of numerous long setae along anterodistal margin; ischium slightly shorter than merus; carpus 2 times as long as merus with patches of setae on inner surface, posterior margin and anterodistal

\section{*To whom correspondence should be addressed \\ Tel: 82-2-880-6695, Fax: 82-2-872-1993 \\ E-mail: wonkim@plaza.snu.ac.kr}




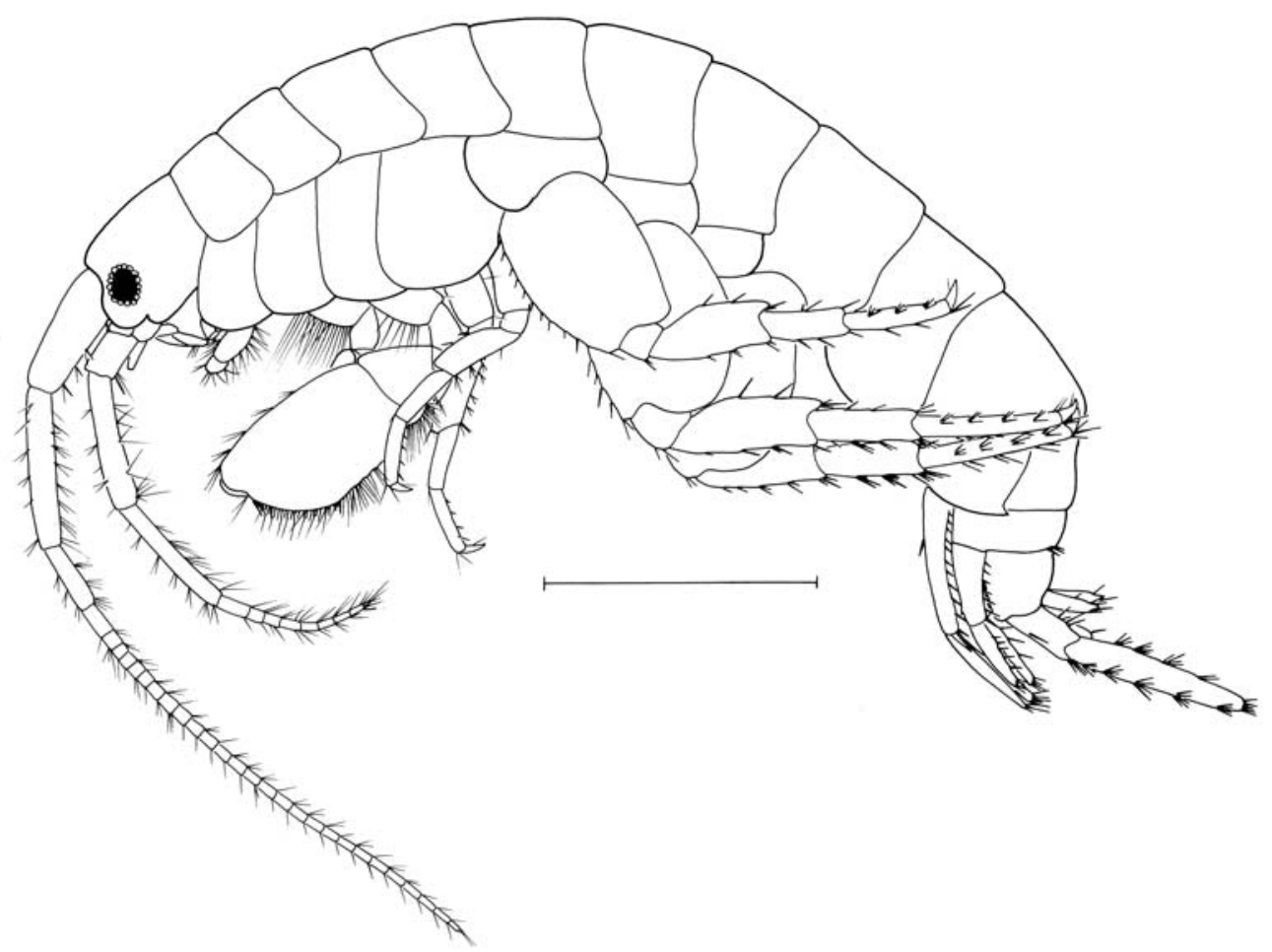

Fig. 1. Melita bingoensis Yamato, male. Body. Scale bar: $2 \mathrm{~mm}$.

lobe, posterior margin convex; propodus with 1 spine on inner surface, anterodistal lobe triangular; excavation of propodus narrow, posterior part produced humplike; dactylus hook-shaped.

Basis of gnathopod 2 (Fig. 2D) 2.6 times as long as ischium; merus having pointed posterodistal lobe; carpus with rounded posterior margin and rows of setae on inner surface; propodus expanded and broadest in middle part, bearing rows of setae on anterior and posterior margins, inner surface covered with many rows of setae; palm bearing densely aggregated small spines; dactylus strong.

Peduncle of uropod 3 (Fig. 2E) about 0.5 times as long as outer ramus; outer ramus uni-articulate, slender; inner ramus scale-like with 1 spine.

Telson (Fig. 2F) with each lobe, bearing one pair of spines laterally and medially on distal margin, and 1 medial spine on inner margin.

Female: Body $6.4 \mathrm{~mm}$ long, slightly smaller than that of male. Anterior lobe of coxa 6 (Fig. 2G) extended posteriorly, its apex bearing 1 small hump, basal part with slit-like shallow pocket and swollen projection.

Distribution. Korea (current study) and Japan.

Remarks. Melita setiflagella Yamato, 1988 is reported to inhabit in brackish water. This species can be distinguished from the other three species by the presence of a row of scale- like denticles on female coxa 6 (Yamato, 1988; Kim et al., 1992). Melita koreana Stephensen, 1944, M. rylovae Bulycheva, 1955, and M. bingoensis Yamato, 1987 are generally found under stones in the intertidal zone at ebb tides. They have morphologically similar characters. However, Melita rylovae is differentiated from $M$. koreana and M. bingoensis by bi-articulated outer ramus of uropod 3 .

Melita bingoensis can be distinguished from $M$. koreana by several distinct characteristics. The propodus of male gnathopod 1 has one spine on inner surface in M. bingoensis, whereas no spine is evident in M. koreana. The epimeron 3 of $M$. bingoensis is more extended posteriorly and has a more distinct tooth than that of M. koreana. In addition, coxa 6 of female in M. koreana is hook-like in form. Above all, the present species has a slit-like pocket in coxa 6 of female which is not found in the other three Korean melitid amphipods. This feature also distinguishes the present species from other species of the same genus in the world.

The morphological features of our specimens coincide with those of Yamato's original description, except for two characteristics: There are three dorsal surface spines on the urosomite 2 in our specimens, whereas there are four in the original description. And, dorsal margin of article 3 in the mandible palp possesses several setae in our specimens, while Yamato's specimens bear only one seta. These differ- 

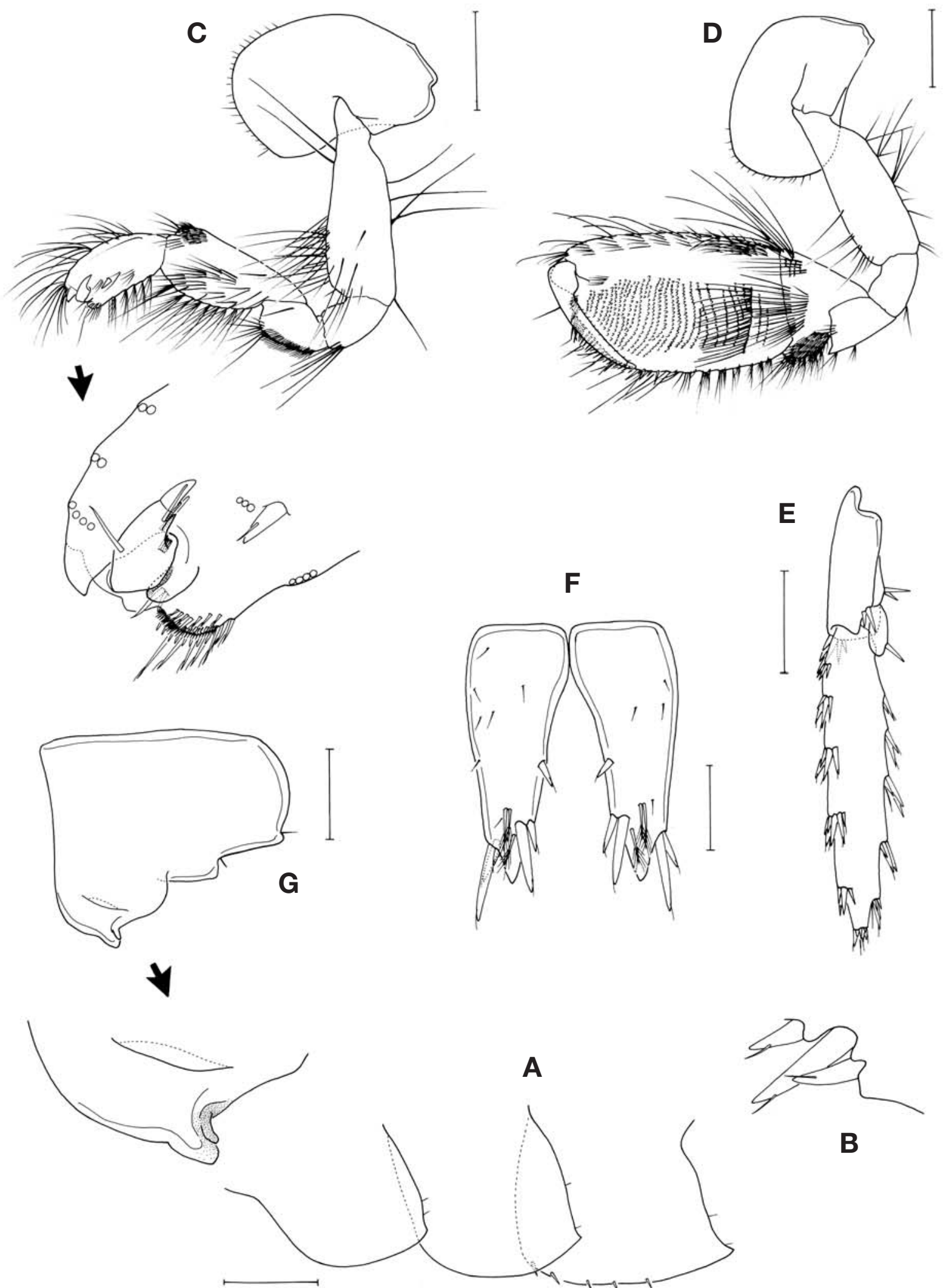

B

Fig. 2. Melita bingoensis Yamato, male. A, Epimera 1-3; B, Dorsal view of urosomite 2; C, Gnathopod 1; D, Gnathopod 2; E, Uropod 3; F, Telson. Female. G, Coxa 6. Scale bars: $A=0.5 \mathrm{~mm}, C-E, G=0.2 \mathrm{~mm}, F=0.1 \mathrm{~mm}$. 
ences are considered to be due to the different size between Yamato's type specimens and our sample. In male, our specimen is larger than the Yamato's type specimens.

\section{ACKNOWLEDGEMENTS}

The present study was supported by a grant from Marine Biotechnology Programme funded by Ministry of Land, Transport and Maritime affairs of the Korean Government.

\section{REFERENCES}

Barnard JL, Barnard CM, 1983. Freshwater Amphipoda of the world. I. Evolutionary patterns and II. Handbook and bibliography. Hayfield Associates, Mt. Vernon, VA, pp. 1-830.

Barnard JL, Karaman GS, 1991. The families and genera of marine gammaridean Amphipoda (except marine gamma- roids). Records of the Australian Museum, Supplement, 13: 1-866.

Kim CB, Kim W, Kim HS, 1992. Three species of the genus Melita from Korea (Crustacea, Amphipoda, Melitidae). Korean Journal of Systematic Zoology, Special Issue, 3:113120.

Shin MH, Kim IH, Lee KS, 2005. Three species of gammaridean amphipods (Crustacea) associated with cultured abalones (Gastropoda) in Korea. Korean Journal of Systematic Zoology, 21:157-169.

Yamato S, 1987. Four intertidal species of the genus Melita (Crustacea: Amphipoda) from Japanese waters, including descriptions of two new species. Publications of the Seto Marine Biological Laboratory, 32:275-302.

Yamato S, 1988. Two species of the genus Melita (Crustacea: Amphipoda) from brackish waters in Japan. Publications of the Seto Marine Biological Laboratory, 33:79-95.

Received May 16, 2011 Accepted June 27, 2011 